the commercial classes in various countries contribute the largest proportion of crime; they are also, as Féré tells us, the most afflicted with nervous complaints, with the exhaustion of the nervous system, so inseperable in some degree or other, from a busy, modern existence, and so fatally linked in its graver forms, with morbid and criminal impulses. The agricultural and mechanic classes, on the other hand, whose pursuits are different, involving less anxiety and fewer temptations, prevent a smaller percentage of crime. The coincidence therefore of the unexampled growth of crime and of industrial activity is justly held to be something more than fortuitous.

It is the fashion to use the vague world "degeneracy" in connection with a condition of the nerves, supposed to be due to modern influences. When the word is employed as it is by Krafft-Ebing, Kurella and Lombroso to describe a peculiar instability of the nervous system, accompanied by definite anatomic variations from the normal type and also by peculiar characteristics of mind, it is undoubtedly indicative of a physical and moral predisposition to crime. A lesser degree of degeneracy, however, that acquired in pursuits too absorbing for the health and strength. may, and does, predispose to crime, especially to homicide, a form of crime committed for the most part by persons who have reached any of the stages of mental and moral deterioration. Nothing, indeed, is more conclusive with respect to the nature of this crime than the fact that an extremely large proportion of the persons convicted of this offence are found to be insane or mentally infirm. Thus of 441 persons convicted of murder in the prisons of England, 143 or 32 per cent. were declared unsound in mind. In short, we are assured beyond any question by these facts and many others that might be instanced, that people who suffer in any degree from maladies of the nervous system, are particularly addicted, as compared with the healthy, to murder; that industrial activity, if too absorbing and severe, may produce various gradations of degeneracy of the mind and nervous system, very often acquired, very often too, inherited, and furnish with its increasing growth one of the predisposing causes of the enormous development of murder in recent years.

There is another circumstance connected with this subject, that I am tempted to touch upon before closing this paper. It is that murder in this country is very frequently committed by persons who act under a notion that they are inflicting just and necessary vengeance. Such crimes, in which category we must place lynchings, happen for reasons of which the discussion belongs more to the sphere of law than medicine. But the distinguishing mark of these crimes for us is that they are nationcl, that is to say, they are caused by the exigencies of a race, not yet in perfect harmony with its environment, that does not seem to know, in fact, the economy $y^{1}$ of crime. I say race, for it is undoubted that, in the regions in which illegal executions are most frequent, a definite nationality has been formed, different in many respects from any type of the Old World. ${ }^{2}$ In other parts of the country the differentiation of the European races in America from any European type is rapidly proceeding, if, indeed, it has not already been consummated as was long ago observed by $\mathbf{M}$. de Quatrefages.. I am inclined to think that a large amount of crime is

Broca: Hist. de la Soc. d'Anthropologie de Paris, 1863, p. $3 \overline{7}$

: Kraffitibing: Psycho-pathologie,p. 2 the result of the play of forces, social and physical, that are at work in this process of differentiation; and until these forces are met on the part of the inhabitants with a better comprehension of how to combat their evil influences, until it is known that the fever of business must subside, that the severities of climate must be mitigated, the excesses of political passions controlled, we may expect, what we have now in frightful amount, an increase in crime.

\section{MEDICAL VIENNA AND HEIDELBERG.}

NOTES FRUM MY SKETCHBOOK.

\section{HARRISON METTLER, A.M., M.D.} CHICAGO, ILL.

Several surprises were in store for me at Vienna. As I approached the city by way of the Danube, a day's sail upon which is as fascinating and full of historic reminiscences as a trip up the Rhine, I began to wonder whether a certain "waltz king" were not the victim of achromatopsia: for the "beautiful blue Danube" is most emphatically a bilious brown in tint. Again when I discovered that the capital of Austria is not on the Danube but a long way back from it on a very muddy canal and a very much muddier creek, my confidence in the veracity of a certain old schoolmaster received a rude shock. To this insignificant creek, the Wien, does the proud city of the Hapsburgs owe its name. Once more to my utter astonishment I found that the great city of Vienna, the real Vienna, is only about a mile long and a halfmile wide, while its apparent bigness is due to the incorporation of some thirty-six or more large suburbs immediately adjoining it. From these suburbs the streets all converge, like the spokes of a wheel, toward the picturesque old cathedral of St. Stephen in the heart of Old Vienna. Unlike most other cities, the aristocratic portion, where the royalty, the nobility and the wealthy have their residence, is the most ancient. The antiquity of this part of the city is revealed in the narrowness of its streets, the height of its buildings, its well paved but undulating thoroughfares, and its numerous dark alleys and covered byways. A touch of orientalism is seen everywhere. Encircling Old Vienna and occupying the site of the ancient ramparts, is a broad and magnificent boulevard, known as the Ringstrasse and adorned with parks, fountains, monuments, statues, and some of the city's finest examples of architecture, among them the splendid University. The circle of suburbs stretches away beyond the Ringstrasse. There is a wealth of history cind legend in OId Vienna; its very life teems with music and art; its people are interesting to know and study; its customs are unique Excepting Paris, Vienna is probably the most beautiful city in Europe. Its architectural elegance equals the brightest visions of the most florid imagination. The first sight of its pomp and splendor so overwhelms the medical visitor with astonishment, enthusiasm and admiration, that it takes him several days to acquire sufficient calm and courage to look up the hospitals and gaze once more upon filthy sores and ugly tumors. But, alas, it must be! Marble palaces, Gothic catheprals, Greek temples, art galleries and museums, royal operas, Hofburg theaters, flower gardens and entertaining music, brilliant arcades, curious statues, magnificent monuments, fretted fountains, gorgeous shops and quaint markets, all must be passed by one who 
would know somewhat of medical Vienna and who has but a few days to learn it in. Medical Vienna, both educational and eleemosynary, is full of interesting history and practical suggestion. Go not then to the city of Marcus Aurelius and Maria Theresa, the carnival city of wine, woman and song, the city of the mystic meerschaum and the home of beauty and art, to study its medical life, unless you go as a student to take up a long residence there. If you go for a few days only, its wealth and magnificence will so enrapture you that your hours will have vanished ere you have had an opportunity of getting even a glimpse of the great University and the vast Imperial Hospital.

As everybody knows, Vienna leads the world at present in general medical education. The mere mention of such names as Billroth, Ludwig, Nothnagel, Chrobak, Schauta, Exner, Benedikt, Kaposi, Politzer, Obersteiner and others, is enough to confirm her preeminence. And yet it was not always thus, for she was long outshone by France and Germany. In neurology and psychic medicine Paris even to-day holds an exalted position; while in pathology and therapeutics Berlin has scarcely a rival. The reasons for the preëminence of Vienna are many. One is the cosmopolitan character, size and wealth of her population. The generous support and favor of the government in educational matters is another. Above all, however, is the unusual concentration of learning in the capital and its matchless University. In Austria university education is pretty much the same as it is in Germany. I will have somewhat more to say about it in my sketch of Berlin. Even in Germany, where learning is so intensely cultivated, the twenty-one universities drain the educational resources of the empire more than do the seven universities of Austria. In both countries the university is a government institution and one of its four or more faculties is always that of medicine.

Within sound of the famous Strauss concerts in the Volksgarten and almost under the shadow of the lace-like Votivkirche rises the superb building of the University. A stone's throw from it are the Rathhaus, as fine a specimen of gothic as one can ever see, the Parliament Building in the style of the pure Greek, the gem-like New Hof-theater, the Law Courts constructed after the most elegant renaissance manner, and many other great buildings, museums and monuments. The Franzensring is a veritable architectural paradise. The designer of the University was Ferstel, one of a brilliant coterie of artists who have added luster to the fame of the royal city. Its style is almost pure renaissance. Immense in size, massive in appearance, and compact, it is nevertheless graceful, chaste and attractive. Its sides are generally plain but its front is broken with galleries, facades and retrenchments. Its cornice is adorned with exquisite moldings, pediments and statuary, while its roof is varied with a large central dome and several smaller domes and cupolas. Its interior is quite as rich and ornate as its exterior, free use having been made of variously tinted marble. The University of Vienna is one of the oldest among the Germanic peoples, having been founded in 1237. Greatly to its advantage, it was reformed under Maria Theresa by her celebrated medical adviser Van Swieten. This famous old courtier physician seems to have been a pretty energetic fellow in his day. $\mathrm{He}$ was born at Leyden in 1700 . $\mathrm{He}$ studied at the university of his native city and that of
Louvain, ultimately becoming a pupil of the immortal Boerhaave. After serving for a time as professor in the University of Leyden, he was forced to resign on account of being a catholic. At once Maria Theresa invited him to Vienna. This was in 1745 . $\mathrm{He}$ was appointed physician to the Empress, director-general of medicine in Austria, imperial librarian, professor and a baron. He wrote much upon surgery, military medicine, epidemics and other related matters. His death occurred in 1772 . Such was one of the liberally educated, representative, old-time physicians who in their immense learning, untiring industry and wide capability stand as a permanent protest to the narrow, technical specialized doctor of the present day. As I stood beside the grave of this famous old doctor in the small but elegant church of the Augustins and in the midst of many magnificent monuments and mausoleums, notably the world-renowned one executed by Canova in memory of the Archduchess Maria Christina, I thought of the honors and dignities conferred upon medical men abroad and compared them with those conferred in America. I fear my head drooped a little and I confess my reflections as a member of the American profession, were anything but self-congratulatory. In every great city of Europe, streets are named, statues erected and public monuments consecrated to the memory of eminent medical men. I began wondering whether the fault lay entirely with our peculiar form of government, or we ourselves were not to blame in a very large measure. I wondered if our numerous ill-prepared colleges, our low standards of medical education, our senseless desire for cheap notoriety, our tolerance of 'isms and 'pathies, our ofttimes badly-concealed efforts to maintain a professional air with a trade-and-barter method of conduct, and especially our too frequent attacks of professional jealousy and absence of laudable esprit de corps, were not after all more in the way of preventing the American people honoring our profession as they should. In the midst of these reflections I strolled sadly out of the church, but took comfort in the thought that the last few years had raised our standard of medical education somewhat and promised better things for the future.

The old university used to be in the vicinity of St. Stephen's church, in a building now occupied by the Academy of Sciences founded in 1846. When it was transferred to its new location it became the center of the educational quarter of the city. The General Hospital, long used for medical teaching, was already there. A short distance beyond were the extensive gardens and superb buildings of the insane asylum for 600 patients. In a neighboring street rose the chemical laboratory, a beautiful renaissance structure designed by Ferstel; while farther along in the same street stood the Josephinum, or Academy of Medicine and Surgery. The latter was founded in 1784 by the Emperor Joseph II. for the training of military surgeons, but afterward he changed his plans. The building to-day contains a remarkable collection of wax preparations illustrating anatomy. In an adjoining edifice, formerly used for the manufacture of implements of war, are the anatomic and physiologic departments. Several military barracks are scattered about the vicinity; while in the midst of them all, occupying the center of a large open platz, rises the magnificent, gothic, highly-ornamented Votivkirche. The study and practice of medicine in Vienna seems always to have been a matter for the considera- 
tion of the state. This may be one reason why the standard of medical education there has always been relatively high. The religious orders have had more of a voice in all educational matters in Austria, otherwise the educational methods have closely simulated those of Germany. It is curious to note that some old statutes of Vienna declare that "medicine is a truly rational science, both as to its theory and its practice." Some modern lawmakers in America, I suspect, do not hold the same opinion! If the applicant for honors were already a master in arts, he was expected to have heard lectures in the medical faculty for at least two years. He would then be entitled to the baccalaureate degree, provided he had heard lectures upon Joannicius, Avicenna and some general work of practice, like that of Rasis Almansor. If he were a candidate for a licentiateship and were the possessor of a degree he was required to attend lectures on medicine for five years. If the authorities found him fit in knowledge and character, devoid of can.
Practical medicine has always had a stronghold in Vienna. As early as the seventeenth century the city contained a large number of hospitals. Its progressiveness is shown in the fact that the first asylum in central Europe, for the exclusive care of the insane, was established here in 1784 . To-day it possesses the largest general hospital in the world and about twentyfour other hospitals, four of which are public institutions, while the rest are more or less private concerns. With a population of about $1,100,000$, its hospital beds number four and a fraction to every 1,000 inhabitants. The oldest hospital in the city was the Borough Hospital of the Holy Spirit, founded by Frederick the Combative in 1240. In 1532 this was removed to the convent of the Clarissa nuns and, like most similar institutions of the time, combined the attributes of a hospital and almshouse. It continued to be the chief important charitable organization of the city for the next 300 years. At one time it sheltered 3,000 souls. It was still an

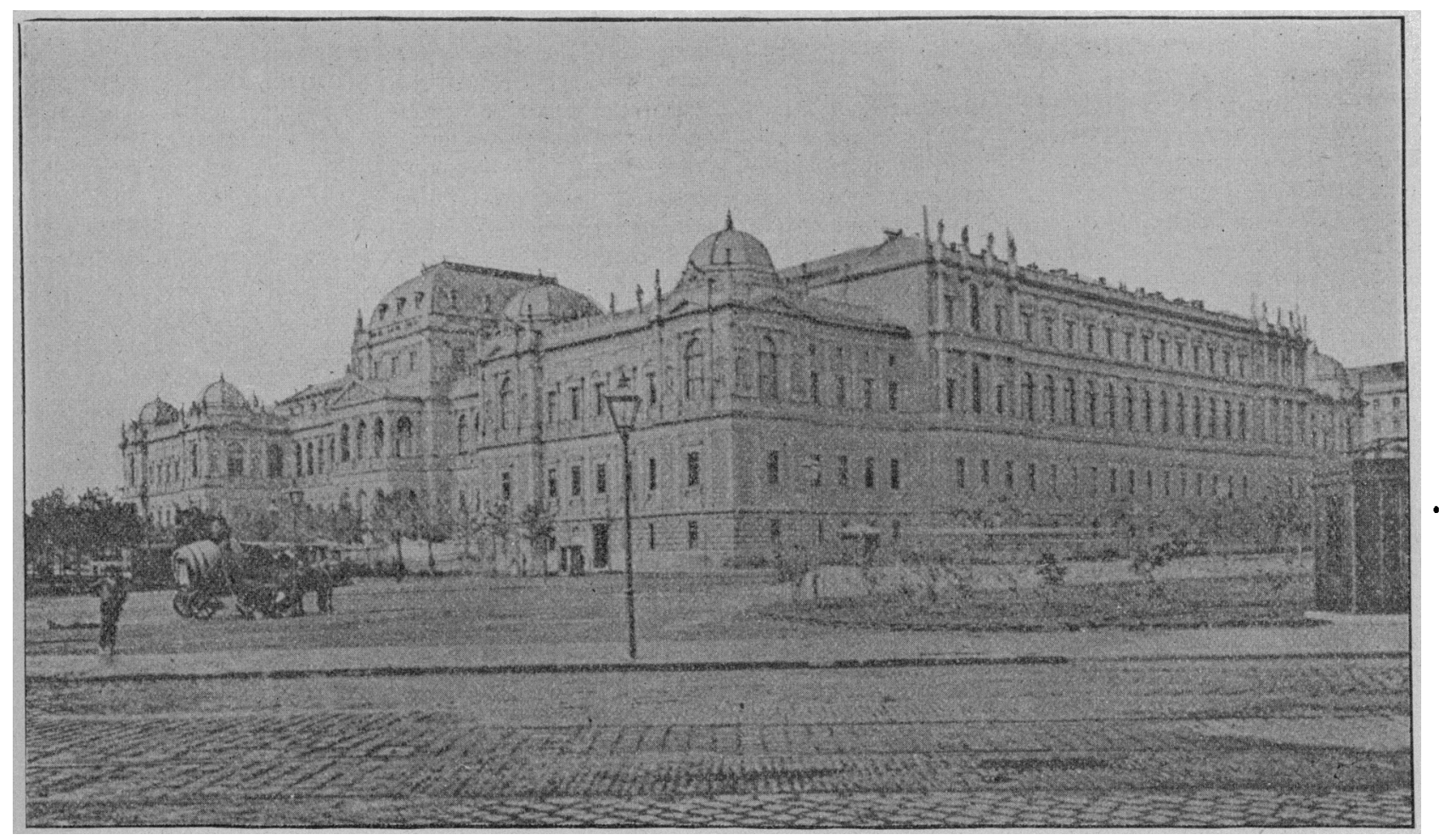

UNIVERSITY BUILDING, VIENNA.

onical impediments, and not too effeminate of counte-jimportant institution in 1754, and was made the seat nance, he might receive his degree at the age of 26 of a medical school in $17 \check{0}$. The reputation of the but strictly not until he was 28. If princes applied medical school had already long vied with that of for a degree and were found wanting, they were Bologna, Paris and Padua. In 1394 St. Mark's Hosrefused on the ground of the statutes. The promo- pital was erected by a private individual, but it was tion of licentiates to the doctor's degree was for many upon two occasions destroyed by the Turks. The years ordered by law to take place in St. Stephen's Emperor Joseph decided in 1780 to abolish the cathedral, where the new doctor was expected to numerous small hospitals throughout the city and to deliver an address in praise of medicine and after. incorporate them into one large establishment. This ward a lecture upon Avicenna, Hippocrates or Galen. was a wise move on the part of the government, for In spite of the comparative ignorance of that day, at the time there were the Crusaders'Hospital built how much more seriously was a medical education by the Knights of the Order for twelve patients, the regarded than is too often the case now! Given the Military Hospital previously used as a lazaretto, the same governmental control and intelligent support/Contumazhof, the Bæckerhænsel with its 300 beds that it enjoyed then, with its modern superiority in for the use of convalescents from the Borough Hosknowledge, how much more exalted and effective pital, the Imperial for the employes of the Court, would be the profession of medicine to-day than it the Spanish, the Trinity and the Strudel Hospitals. actually is!

In the amalgamation of these various institutions, the 
monarch appropriated the old workhouse which had construction. Without doubt, it is, except architectbeen founded nearly a hundred years before by Leo- urally, a model hospital. Of course were a new building pold I., and established beneath its roof the medical to be erected many improvements would be required school as well as the new hospital. The building had for the sake of light, air, ventilation and general at nirst been used as a Hotel des Invalides for retired cheerfulness. As is the case with many other hospisoldiers and theirfamilies. Additions and alterations tals in Europe, antiquity must be pleaded as an were made and the whole opened, in 1784, as the excuse for shortcomings. Small windows, low corriGeneral Hospital, or Allgemeines Krankenhaus, dors, curious old.fashioned doors, rambling halls, which has since become world-renowned. For a musty dark corners, irregular floors, cracked walls and long time it contained departments for maternity narrow apartments are not entirely uninteresting, for cases, lunatics, foundlings and the sick in general. they speak of the past with its suggestiveness of quaint In 1834 extensive additions were made to the hospital story and feudal history. But in a modern hospital and again in 1862. The maternity cases, the lunatios they are not altogether compatible with the modern and the foundlings were separated and placed under ideas of surgical requirements and hygienic perfeca different management in 1860. In 1887 the hos- tion. The wonder is that in these old hospitals such pital contained 2,000 beds and treated some 25,796 splendid results are so often attained. It bespeaks cases. Surgery has always been an important feature of its work.

A few details in regard to the management of this great and model hospital may be of interest. The government controls it and the same management includes the care of the Royal Rudolph with its 860 beds and the Royal Wieden with its 597 beds. The General Hospital has a director, who draws a salary of 3,800 florins (the florin being equivalent to about 49 cents of our money), and a superintendent. The med. ical staff is paid by the directors out of the hospital funds and includes five senior physicians and five senior surgeons. Each has three assistants. There are 16 dressers. The senior members of the staff get a salary of 1,800 florins per annum without residence. The nursing staff numbers 226 , all of them being lay women except 12 male attendants. The nurses average about 1 to every 10 patients. Their compensation is from 12 to 16 florins per month, with board, washing and uniform. Members of certain religious sisterhoods attend to the nursing in the Rudolpli and Wieden. The General Hospital is of course a public charity but it receives three classes of paying patients, namely, those who desire the best accommodations at 5 florins per day, those who can give 2 florins, 50 kreutzers per day and finally those who are satisfied with the accommodations afforded for 1 florin, 7 kreut. zers per day. Incurable and obstetric cases, as well as children under 4 years of age, are not admitted. The expenses of the institution are met by a Royal Hospitals fund and a reserve fund, both of which are made up from various sources such as interest upon the original capital invested, legal tolls and duties, payments from patients, subscriptions and voluntary donations.

The Allgemeines Krankenhaus covers an area of nearly 25 acres and consists really of a series or conglomeration of hospitals. There is nothing to be said of it architecturally. It is an old-time structure and when I first visited it, toward the latter part of a clear afternoon, I could scarcely believe that I had actually arrived in front of the world-renowned institution. Plain, low and unornamental, it produced in me a feeling of intense disappointment. A photograph of it would scarcely have been worth the trouble of taking. It is an immense rectangular structure surrounding a spacious courtyard and having various irregular, inharmonious wings attached. As I afterward strolled through many of its halls and wards, having been favored with letters of introduction to several members of its staff, I was impressed with the cleanliness and precision with which everything was done in spite of the many inconveniences and ancient. unusual attention to details, a systematic exactness and an exceptional skill on the part of the attendants. And after all that may be one of the causes of the supremacy of some of the foreign schools of medicine. The continuous bath for the treatment of skin diseases is a feature in the clinical work of the General Hospital. Besides this hospital mention should be made of the Inquisiten with its 163 beds, the new and attractive Favoriten with its 560 beds and the St. Anne's. Vienna is supplied also with a most excellent Smallpox and Epidemic Hospital, the latter having been erected at the time of the cholera outbreak in 1873 and the first to be constructed in the pavilion style, at a cost of some $£ 39,000$. It contains about 300 beds. HEIDELBERG.

One marvels how a town of only 22,000 inhabitants, and a singularly salubrious town at that, can possibly furnish a sufficient variety of diseases for the maintenance of a school in practical medicine. And yet Heidelberg, known among tourists chiefly for its fine old German castle, its great tun and its dueling students, is one of the most celebrated seats of medical education in all the German empire. It contains a hospital of nearly 400 beds and the medical faculty of its famous university ably maintains the ancient renown of the school. Such distinguished names as Tiedemann, Gegenbaur, Kuhne, Crerny, Erb and Vierordt would add luster to the name of any university. Many a traveler has departed from Heidelberg, after viewing its principal sights and hunting high and low in vain for the university of which he had heard so much, with possibly a feeling of doubt and disappointment as to the veracity of Dame Rumor. To know scholastic Heidelberg one must reside a short time there. The town itself consists chiefly of a single long street, lined on both sides with many an interesting old building, quaint shop, open plaza and curious church, all crowded together as in a vise between the swift flowing Neckar on one side and the wooded Geisberg, with the famous Schloss halfway up its declivity, on the other. Minor streets and byways of course branch off from the main thoroughfare and here and there revive memories of Goethe. Schiller, Martin Luther, Jerome of Prague, Tilly, Gustavus Adolphus and other great names in history, science and romance. Not only is the situation of the town one of the most picturesque in Europe, but its history is one of the most exciting. Scarcely less fascinating, however, is the story of the university, which, next to the universities of Prague and Vienna, is the oldest in Germany.

One day as I was sauntering about the town, having 
in despair almost relinquished my efforts toward finding the university, I was made aware of the presence of an unusual number of student-like fellows hurrying hither and thither in the Ludwigsplatz. I imagined I must at last have arrived in the neighborhood of the school. I looked sharply about me and began getting my letters of introduction ready, but I saw no magnificent edifice anywhere, and so concluded I had again lost the trail. As I was passing through a narrow street, hoping to encounter some one who would revive my hopes by giving me the desired information, I happened to pass a small open doorway in a long, low, insignificant building that did not seem at least to be a private residence. I entered, and what was my astonishment to find, after reading some inscriptions in the vestibule, that at last $I$ was within the walls of the great University of Heidelberg. It came home to me then and there with tremendous force, that buildings do not make universities. Could it be possible, I mentally exclaimed, that the grand old school of Heidelberg occupied no more pretentious structure than this! Truly was it said that the university building is very much like a huge model lodging house in a bad state of repair, being merely a large, plain stucco structure at one side of a bare open platz, appearing as desolate as Gray's Inn Square upon a Sunday. In size and beauty (if, indeed, it may be said to have any) the miversity is quite eclipsed by its neighbor across the square, the museum. There are no grand open doorways, no Corinthian columns, no majestic peristyle, no towering domes or cupolas, nothing but four flat walls. The anatomic and chemic departments are in another part of the city, and housed in fairly artistic buildings in comparison with the university itself. I would that space allowed me to do more than simply outline the history of this fine old seat of learning, one of whose most important departments is that of medicine, for as I strolled about it and learned more of its life, I grew fonder of it. It was founded in 1386 by Rupert I., purely as an ecclesiastic institution. The Bishop of Worms was its first chancellor, and its faculty consisted entirely of priests and members of the monastic order. Hence it stuck like a leech to the old scholastic doctrines during the troublous times of the Reformation, and always opposed itself to the new learning which later on had its head and source up in the castle. Only in the last century has this favored old school awakened to the progress of the world, and in that short time made itself a reputation for brilliant scientific discoveries. When we recall its stagnant conservatism, what a wealth of sarcasm there is in Pope Urban's bull of 1385 , wherein he states that the "town of Heidelberg, which in view of its healthy situation and air and its fertile surroundings, is admirably adapted to form a universal fountain of the scitnces." The first statutes of the university were drawn up by Marsilius von Inghen, a former instructor in the University of Paris. The students were required to attend the lectures daily on pain of losing their rights of membership and final certificates. The highest salary paid to any professor was given to Marsilius, and consisted of about $£ 20$. The tutors usually received $£ 5$ or 50 florins, a pretty handsome sum, I presume, for that day, but scarcely enough for shoe polish in this! Great privileges had this old university. Note some of them for curiosity's sake. All attendants, as well as all who were brought in contact in any way with this "beloved daughter" of Rupert
I., such as booksellers, bookbinders and servants of the tutors, were amenable to the jurisdiction of the university only and were exempt from all taxation.

By a commission, the board of the students for one week was to be about three farthings. Three farthings, think of it! The good folk of the village who cared to board any of the students were not required to pay octroi or city toll duties. And again, if any of those old Heidelbergers laid violent hands for any purpose whatever upon those precious students, they were obliged to pay a "fine of 60 florins and damages." Every year the magistrates were compelled to take oath that they would not infringe upon the rights of the fondling of Rupert. A pretty mess all these favors soon concocted and as a result students' wars and other "great uproars arose" until old Rupert himself had to hasten down the hill and force the town to behave itself. In all sorts of ways the succeeding electors petted and nurtured this spoilt child of theirs and how little did it give in return! Nothing but a lot of theologic truck and a fierce opposition to the advancement of knowledge. At last the electors became tired of all this and one of them, Otho Henry, he who built the charming Heinrichsbau of the castle, "resolved to make the university flourish again even though it should cost him his last farthing." This. Henry had vim in him and no scholastic nonsense was able to turn him from his purpose of awakening once more the spirit of intellectual progress. Inviting Melancthon, the companion of Luther, to join him, a quartette was formed, including Henry himself, Melancthon, the councillors Ehem and Propus, to whom was also added the classicist, Micyll, to undertake the remodeling of the school. Success attended their efforts and the ancient scholastic methods were abolished. The library was enlarged and the whole institution placed on a firmer basis. Many famous scholars and teachers occupied its chairs. When Heidelberg was destroyed in 1693 during the war, the university was also burnt. The faculty fled for their lives, but continued their lectures at Frankfort and Weinheim. In 1700 the university was reëstablished but during the eighteenth century it was again under the influence of religious conservatism. During the Napoleonic upheavals it received a terrible blow, but in 1803 the Elector of Baden revived it again and placed it on a new foundation, since which time its reputation has steadily increased until now it is one of the noted schools of Europe. The medical department has awakened to new life, and such men as Czerny and Erb and Kuhne have brought it fame. The students of Heidelberg are always proud of their school. To-day they retain many of their privileges, and the easy going burghers are judiciously gracious to them. Dueling is one of the drawbacks, but the abolition of that is under consideration. The merry celebrations, the jovial concourses with rollicking songs and huge tankards of beer, make college life in Heidelberg an episode in one's existence never to be forgotten. Whatever trials he may have passed through, however far he may have wandered, whether high or low be his station in life the old alumnus of Heidelberg recalls with indescribable delight the democratic days of his youth when shoulder to shoulder with emperors' sons, princes and future savants he drank his beer, roved over the neighboring mountains and imbibed the pleasures of knowledge in his dear old alma mater beside the swift-flowing Neckar. 
As many American physicians visit Europe, and as medicine is the same there as it is on this side of the water, I thought the limited space at my disposal would probably be more interestingly occupied with these brief notes upon Vienna and Heidelberg than with a description of familiar clinics and technical details.

4544 Lake Avenue.

\section{SELECTIONS.}

Obstruction of the Bile Duct.-At the annual meeting of the New York State Medical Association, Oct. 14, 1896, Dr. Henry $O$. Marcy of Boston contributed an interesting paper upon the "Surgical Relief of Obstruction of the Common Duct by Biliary Calculi." He gave a review of his special studies upon biliary obstruction, which commenced in 1876, with detailed reports of cases, occuring in 1880 and 1881, where he urgently advised operative procedures for the relief of biliary obstruction. Postmortem examination showed that the causes of the obstruction was a biliary calculus lodged in the common duct. Operative interference was refused since there was no record of surgical procedures having ever been attempted for this purpose, and the agreement of the consultants that it was probable that the obstruction was in the common duct. Autopsy showed that operative interference would have been not only possible, but that the conditions were favorable for surgical interference. Dr. Marcy performed his first operation in July, 1887 , and although unsuccessful in the removal of the gallstone, because of intestinal adhesions, the calculus was dislodged and the patient recovered, followed by a short period of relief. Later the autopsy demonstrated that the calculus was in the common duct with a limited range of movement. Afterward Dr. Marcy criticized his operation, believing that the duct might have been opened and the calculus removed, followed by immediate suture of the wound in the duct, with a reasonable degree of safety. Dr. Marcy gives a careful detailed history of his first case of successful operation for the removal of a calculus from the common duct which occurred in his private hospital Oct. 26, 1889. Here the calculus was imbedded in the common duct so firmly that the backward pressure of the bile through the cystic duct had caused the gall bladder to be so enormously dilated that its contents measured ten ounces. Other methods of removal having failed, the gall bladder was divided with scissors through its cystic portion, until the calculus was reached and removed. This was nearly globular, about the size of a large filbert, which weighed fifty-nine grains when dry. The entire wound in the viscus measured four inches. It was immediately closed with a fine, continuous tendon suture in three layers, the first including the mucous membrane, the second the entire wall, while the third was taken from side to side as a parailel suture which, when drawn upon, evenly intrafolded the peritoneum over the wound, itself completely buried from sight. The abdominal wall was also closed in layers with tendon sutures, without drainage. The patient made an easy, uninterrupted recovery and continues well at the time of writing. Dr. Marcy's first publication upon this subject was read at the meeting of the American Medical Associatron, held at Nashville in May, 1890. He reports his subsequent experiences as more than satisfactory and gives his fullest approval to the advisability of surgical relief in biliary obstruction caused by a calculus in the common duct. Dr. Marcy's paper is of the greater importance, since he was the first to attempt the operation, and the first to operate successfully for the removal of a biliary calculus in the common duct. Courvoisier, to whom the credit of the first operation has been given by one writer, performed his first operation Jan. 22, 1890.
Malignant Tumors Treated with Toxins of Erysipelas and Bacillus Prodigiosus; Series of 160 Cases.-In the Bulletin of the Jolns Hopkins Hospital, August, appears a discussion of Dr. W. B. Coley's toxin treatment of malignant growths. Dr. Coley showed that his experience had extended over a period of more than four years, that the tumors sent to him for treatment were for the most part such as had been pronounced inoperable by leading surgeons, and that the diagnosis of malignancy had been determined, in practically all the cases, by a competent microscopic examination.

An analysis of the cases treated showed that 48 were roundcelled sarcoma, 13 spindle-celled, 7 melanotic, 2 chondro-sarcoma, 3 mixed celled, 14 sarcoma, special type not known. Total number of cases of sarcoma 93, carcinoma and epithelioma 62 cases, sarcoma or carcinoma 10 , tubercular 2 , fibroangioma 1 , mycosis fungoides 1 , goitre 2 , keloid 1 . Of the cases of sarcoma, nearly one-half showed more or less improvement the variety that showed the greatest improvement was the spindle-celled, that which showed the least, the melanotic. Next in order of benefit was the mixed celled-.-round and spindle; then round celled, while osteo-sarcoma closely approached the melanotic in showing but little change. In a series of nine cases of melanotic sarcoma, no improvement was noticed in six, very slight in three. Most of the cases of osteosarcoma failed to respond to the treatment, many showed slight improvement and one case, a very large osteo-chondro-sarcoma of the ilium, apparently disappeared and the patient remained well for nearly a year, when a recurrence occurred. One case of round-celled sarcoma of the neck of very rapid growth showed very marked decrease during the first week's treatment, after which time it continued to grow in spite of large doses of toxins. The writer stated that he did not expect the profession at large to accept without question and criticism such remarkable results as he had reported, and for that reason he had related with some detail the successful cases in the hands of other surgeons who had employed this method. He was of opinion that a series of upward of twenty successful cases of inoperable sarcoma (four of which had remained well upward of two and a half years), the diagnoses of which had been established beyond question according to accepted methods of diagnosis, ought to be sufficient to demonstrate the real and positive advance that had been made in a field which, up to this time, had been regarded as absolutely hopeless. He did not doubt that there were those who would still remain skeptical about the value of the toxins in spite of the evidence presented. Such persons must either fail to see any logical connection between the accidental erysipelas and the toxins, or they must go even farther and deny that there are any authentic cases of malignant tumors that were cured by accidental erysipelas. The only explanation they can have to offer for the results which can not be questioned is, that in all the successful cases there must have been an error of diagnosis.

Remarks by Dr. W. H. Welch : "I have been much impressed by this personal statement from Dr. Coley, and I see no way of gainsaying the evidence which he has brought forward, that there is something specifically and genuinely curative in his method of treatment. A single undoubted cure of a demonstrated cancer or sarcoma by this treatment would be enough to establish the fact that the treatment exerts some specific curative effect, for the spontaneous disappearance of undoubted malignant growths of this character is almost unknown. Dr. Coley has, however, presented to us positive proof of the cure, not of one only, but of several cases of malignant tumor by his method. Although I suppose in any given case the chances of cure by this method are at present not great, still the demonstration that cure is possible gives every encouragement for perseverance in this line of investiga tion and work, and for efforts to perfect the method of treatment. It is interesting to learn that the most strikingly beneficial results have been obtained in the treatment of spindle. celled sarcomata. There are certain kinds of sarcomata which some pathologists are inclined to rank rather among the infec tious tumors than among the genuine tumors, in the sense in 